\title{
Polypharmacy simulation and pharmacotherapy perceptions among students from a university in Ceará: a pilot study
}

\author{
Simulação de polimedicação e percepções sobre farmacoterapia em estudantes de universidade no Ceará: \\ estudo-piloto
}

\author{
Yuri M. Bezerra' (D) yuribzr@icloud.com \\ Isabelle de Sousa Pereira' (D) isabellesousapereira@gmail.com \\ Rafael D. Sarubbi' (1) rafaelds99@gmail.com \\ Antônio Brazil Viana Júnior ${ }^{2}$ (1) brazil.estatistico@gmail.com \\ Ana Rosa P. Quidute' (1) arquidute@gmail.com
}

\begin{abstract}
Introduction: Given the high prevalence of polypharmacy patients, it is paramount that they be handled with an effective therapeutic alliance and with safe and feasible treatments. Empathy towards the patient is essential, and the lack of prescriber experience may hamper such bond. Objectives: This study simulates a polypharmacy regimen among medical students, aiming to promote reflections about the daily challenges faced by patients.

Methods: It is a prospective study in a single, non-blind group. The participants were medical students and residents from our institution, all of whom followed a 7-day placebo prescription. They answered questionnaires on their perceptions of medication adherence and concordance before and after the simulation.

Results: twenty-eight volunteers participated, 27 of which (96.4\%) forgot to take at least one pill during the experiment. Among the lower undergraduates, $28.57 \%$ interrupted at least one medication. As for the higher undergraduates and residents, this happened with $71.43 \%$ of them. There were more adherence failures than predicted by the participants themselves. In realistic dosages, levothyroxine, angiotensin-converting enzyme inhibitors and metformin were the drugs reported to be the most difficult. $96 \%$ of the volunteers strongly agreed that doctor and patient's agreement regarding the treatment correlates with good adherence.
\end{abstract}

Conclusion: Understanding the factors that affect adherence and how to handle them is essential for a doctor, as well as a good bond with the patient. The teaching of these abilities is very necessary. Further studies are needed to reach more undergraduate students and to highlight the relevance of simulations in the medical education setting.

Keywords: Polypharmacy; Treatment Adherence and Concordance; Simulation; Medical Education.

\section{RESUMO}

Introdução: Com a prevalência de pacientes polimedicados, é essencial que estes sejam manejados com aliança terapêutica efetiva e tratamentos factíveis e seguros. A empatia com o paciente é indispensável, e a falta de experiência dos prescritores pode impedir esse vínculo. Objetivo: O presente estudo simula um regime polimedicamentoso com acadêmicos de Medicina, para promover reflexões sobre as dificuldades vivenciadas pelos pacientes.

Método: É estudo prospectivo em grupo único e não cego. Participaram estudantes de Medicina dos semestres 5 a 7, internos e residentes da nossa instituição, que seguiram regime placebo por sete dias. Antes e depois do período, os voluntários responderam a questionários de percepções sobre aderência medicamentosa e concordância terapêutica.

Resultado: Participaram 28 voluntários, dos quais $27(96,4 \%)$ esqueceram-se de utilizar pelo menos uma medicação durante o período. Dos graduandos, $28,57 \%$ referiram interrupção do uso de pelo menos uma. Do grupo de internos e residentes, essa porcentagem foi de $71,43 \%$. Houve mais perdas de dose do que o previsto pelos participantes. Seguindo posologias realistas, levotiroxina sódica, inibidor de enzima conversora da angiotensina e metformina foram os fármacos referidos como de maior dificuldade. Do total de participantes, 96\% afirmaram com veemência que o tratamento acordado entre médico e paciente deve se correlacionar com a boa aderência terapêutica.

Conclusão: A compreensão sobre os fatores que influenciam na aderência e em seus manejos é indispensável na capacitação do médico, bem como o bom vínculo entre médico e paciente. O ensino dessas habilidades é necessário. São necessários estudos adicionais, a fim de alcançar mais graduandos e ressaltar a relevância de simulações no ensino médico.

Palavras-chave: Polimedicação; Cooperação e Adesão ao Tratamento; Simulação; Educação Médica.

1 Universidade Federal do Ceará, Fortaleza, Ceará, Brazil.

${ }^{2}$ Hospital Universitário Walter Cantídio, Fortaleza, Ceará, Brazil.

Chief Editor: Rosiane Viana Zuza Diniz.

Associate Editor: Maurício Abreu Pinto Peixoto.

Received on 01/31/21; Accepted on 06/11/21.

Evaluated by double blind review process. 


\section{INTRODUCTION}

Adherence or drug adherence (DA) is defined as the degree to which patients cooperate with the medical prescription ${ }^{1}$. Nonadherence allows the persistence of high morbidity and mortality rates for patients and high costs for health systems ${ }^{2,3}$. For instance, the quality of life was directly correlated with the degree of DA in an elderly population assisted by the Unified Health System (SUS, Sistema Único de Saúde) in southeastern Brazil ${ }^{4}$, with poor DA being the main cause of heart failure decompensation in 51 centers in the country 5 .

Obstacles to DA include intrinsic patient factors, factors specific to the chosen therapy and factors related to the underlying disease, which interact as shown in Figure $1^{3}$. For the former, advanced age, young age or immaturity, low health literacy, disbelief in oneself or in the care team and a culture that does not believe in medications can harm the therapy. The drug regimen itself can discourage an adequate implementation, through adverse effects, lack of symptoms in its absence, multiple daily doses, multiple concomitant treatments, and restrictions on previous lifestyle habits. The pathology itself also affects the outcome of DA, if it is asymptomatic, if requires polypharmacy at the onset or interferes with the patient's physical or mental performance ${ }^{3}$. Cost is also an important interfering factor in Brazil ${ }^{6,7}$, since not all medications are available through SUS, or, if they are, they can be obtained only in select doses and may be lacking ${ }^{6,8,9}$. There is also the bureaucracy to obtain certain medications, which are expensive or carry potential risks, materialized as the recurrent need for re-registration and exams to obtain them, which discourage the medication protocol continuation.

The Brazilian population is aging ${ }^{10}$ in a scenario in which the average number of medications per elderly in an outpatient setting is $4.5^{11}$, disclosing a potential increase in the number of polymedicated patients and associated adversity costs. Brazil is also the second-largest country in the number of solid-organ transplants ${ }^{12}$, a procedure with high cost and morbidity, with a higher risk of failure and consequent human and health costs in the absence of adequate adherence to the immunosuppressive therapy ${ }^{13}$.

In this context, a good relationship between doctor and patient is an indispensable condition ${ }^{11,14,15}$ for good concordance, degree of understanding and mutual cooperation regarding the therapy. It is consistent ${ }^{3,15}$ that the patient needs to understand how to use the drugs and participate in the choice of a regimen that suits their routine and needs to adequately comply with the prescription. In order to improve adherence and concordance, medical prescriptions must be improved, especially in polypharmacy, making physicians and medical students aware of the barriers to drug therapy.

Thus, the present study was carried out, replicating a previous study by Perdue et al., aiming at simulating a common polypharmacy regimen in clinical practice with students at our institution for one week, evaluating the degree of adherence to different doses and understanding the impact of simulation regarding the participants' perceptions of concordance. The simulation was chosen as an instrument because it is an effective suggested method for teaching empathy, especially when the students puts themselves in the patient's place, in a systematic review on the subject ${ }^{16}$. This specific methodology is not part of the institution's current curriculum, and the present analysis is the result of a pilot project to assess its implementation in the curriculum.

\section{METHOD}

The research project was approved by the Research Ethics Committee of the institution under CAAE number

Figure 1. Interaction between determining factors of DA.

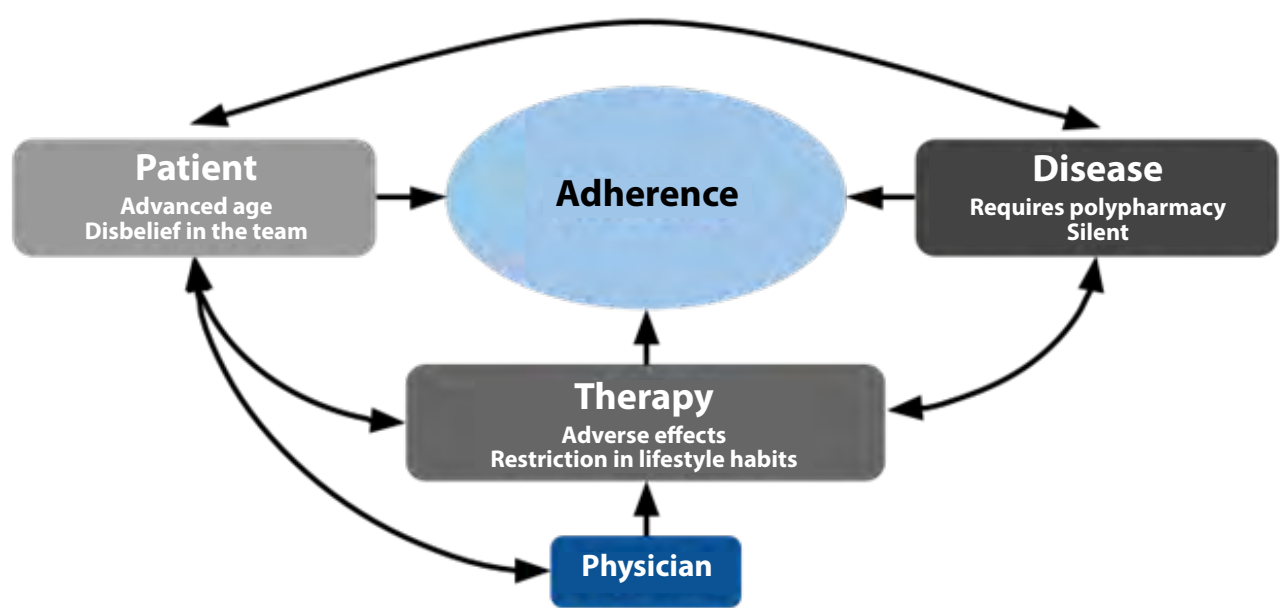

Legend: DA is defined by the interaction of disease, therapy and patient factors, with the last two being susceptible to interference by the physician. For each adherence modifier, there are several distinct variables. 
16142819.1.0000.5054. The study was a prospective, quasiexperimental, single-group and non-blind study, with a sample of medical students, interns and residents. The inclusion criteria were: being healthy at the time of the study, negative history of severe illnesses and being an adult (age $>18$ years). For the student group, another criterion was attending the $5^{\text {th }}, 6^{\text {th }}$ and $7^{\text {th }}$ semesters of the course to ensure clinical experience without autonomous or semi-autonomous drug prescription. Medical internship students and medical residents linked to the institution comprised a group that had experience in prescribing. To maintain the uniformity in the amount of medication used and to avoid possible therapeutic interference, individuals who used any type of drug were excluded.

The project was announced online for one month. Voluntary enrollment consisted of a survey on demographic, academic and specific data for screening by inclusion/ exclusion criteria.

The volunteers completed the Free and Informed Consent Form (FICF) and pre-test on adherence (Brief Medication Questionnaire, version validated in Portuguese, authorized for use by the authors ${ }^{17}$ ), which was used at that time to obtain adherence expectations for the week of the simulation, and concordance (Leeds Attitude to Concordance II, Knapp et al., as a free translation, of which use was authorized by the authors ${ }^{18}$ ). Subsequently, they received an explanatory text, a fake prescription and bottles containing empty polysaccharide capsules, without an active ingredient, corresponding to the placebo medications, produced by the institution's School of Pharmacy.

The simulation consisted in the use of the following regimen with inert capsules for seven full days: angiotensinconverting enzyme inhibitor, 01 capsule 03 times a day; Levothyroxine Sodium, 01 capsule once a day on an empty stomach (30 minutes before breakfast); metformin, 01 capsule twice a day with meals (lunch and dinner); thiazide diuretic, 01 capsule once a day; and calcium-channel blocker, 01 capsule twice a day. Thus, each participant was instructed to take 9 inert capsules a day, mimicking an outpatient regimen common in clinical practice. The capsule that simulated metformin was larger than the others, since this is one of the characteristics of the presentations available in the national market.

After the end of the simulation, there was a second meeting, in which the research participants returned their remaining capsules and answered a post-test on adherence and concordance. The remaining capsules, dropouts and absences were counted.

The data were presented in tables and graphs for the statistical analysis. Numerical variables were presented as mean, standard deviation and median values. Frequency and prevalence rate were used to express the categorical variables. The comparison of the study pre- and post-test scores was performed using the Wilcoxon test. The JAMOVI 1.6 software was used to perform the analyses. A 95\% confidence level was adopted in this study.

\section{RESULTS}

In total, 44 volunteers were enrolled in the project. Of the 44 enrolled, 28 (64\%) met the inclusion criteria, whose mean age was $21 \pm 4.09$ years (25-36), of which 13 were women. Twelve volunteers were using some type of drug at the time of study enrollment, which was an exclusion criterion.

Of these, 21 were students attending the clinical cycle of the medical course. Four medical interns and 3 residents of the institution comprised the group with the greatest experience in prescribing. All of them completed the pre- and post-test of adherence; 25 completed the pre-test and 21 the post-test of concordance. Of the students attending the clinical cycle, 2 were in the fifth semester, 13 in the sixth and 6 in the seventh semester.

Of the students, 06 (28.57\%) undergraduates attending the $5^{\text {th }}, 6^{\text {th }}$ and $7^{\text {th }}$ semesters reported the interruption of at least one placebo medication. The medications that showed the best adherence were levothyroxine and the thiazide diuretic, while the ones with worst adherence were metformin and the calcium-channel blocker, although the ones reported as the most difficult to use were levothyroxine (4 observations) and the angiotensin-converting enzyme inhibitor (4 observations). The students estimated the number of times they would forget to take each medication, which was consistently less than what actually occurred. Some students reported that they ignored the need for fasting. Group adherence occurred as indicated in Table 1. According to the table, approximately 420 capsules were returned of a total of 1,323 dispensed ones.

Of the group of interns and residents, 5 of 7 (71.43\%) reported discontinuation of at least one placebo medication. The medications that showed the best adherence were thiazide diuretics and angiotensin-converting enzyme inhibitors, while the ones with the worst adherence were levothyroxine sodium, angiotensin-converting enzyme inhibitors and metformin, with all of them also being reported as difficult to use (4 reports for each). The members of this group also estimated the number of times they would forget to take each medication. Group adherence occurred as indicated in Table 2. According to the table, approximately 690 capsules were returned, out of 1,323 dispensed ones.

Twenty-seven of the 28 participants missed some dose. The absolute adherence and concordance scores at both times of the study are displayed and compared in Table 3. 
Table 1. Details of the adherence by drug administered to medical students $\left(5^{\text {th }}, 6^{\text {th }}\right.$ and $7^{\text {th }}$ semesters).

\begin{tabular}{|c|c|c|c|c|c|c|}
\hline Simulated drug & Indicated posology & $\begin{array}{l}\text { Final \% of } \\
\text { taken doses }\end{array}$ & $\begin{array}{l}\text { Expected \% of } \\
\text { taken doses }\end{array}$ & $\begin{array}{c}\text { Amount } \\
\text { dispensed by } \\
\text { participant }\end{array}$ & $\begin{array}{l}\text { Mean final } \\
\text { returned } \\
\text { amount }\end{array}$ & $\begin{array}{l}\text { Mean expected } \\
\text { returned } \\
\text { amount }\end{array}$ \\
\hline Levothyroxine Sodium & $\begin{array}{c}1 \text { cap., once a } \\
\text { day under fasting } \\
\text { condition }\end{array}$ & $77.9 \%$ & $78.1 \%$ & 7 & 1.55 & 1.53 \\
\hline Metformin & $\begin{array}{l}1 \text { cap., twice a day } \\
\text { with meals }\end{array}$ & $62.4 \%$ & $85.7 \%$ & 14 & 5.27 & 2 \\
\hline $\begin{array}{c}\text { Angiotensin-converting } \\
\text { enzyme inhibitor }\end{array}$ & 1 cap., $3 x /$ day & $62.8 \%$ & $82.3 \%$ & 21 & 7.82 & 3.71 \\
\hline
\end{tabular}

Abbreviations: cap.: capsule. \%: percentage.

Table 2. Details of the adherence by drug administered to medical interns and residents.

\begin{tabular}{|c|c|c|c|c|c|c|}
\hline Simulated drug & Indicated posology & $\begin{array}{l}\text { Final \% of } \\
\text { taken doses }\end{array}$ & $\begin{array}{l}\text { Expected \% of } \\
\text { taken doses }\end{array}$ & $\begin{array}{c}\text { Amount } \\
\text { dispensed by } \\
\text { participant }\end{array}$ & $\begin{array}{c}\text { Mean final } \\
\text { returned } \\
\text { amount }\end{array}$ & $\begin{array}{c}\text { Mean expected } \\
\text { returned } \\
\text { amount }\end{array}$ \\
\hline Levothyroxine Sodium & $\begin{array}{c}1 \text { cap., once a } \\
\text { day under fasting } \\
\text { condition }\end{array}$ & $42.9 \%$ & $69 \%$ & p & 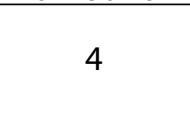 & 2.17 \\
\hline Metformin & $\begin{array}{l}1 \text { cap., twice a day } \\
\text { with meals }\end{array}$ & $44.9 \%$ & $94 \%$ & 14 & 7.71 & 0.83 \\
\hline Thiazide diuretic & 1 cap., once a day & $57.1 \%$ & $83.3 \%$ & 7 & 3 & 1.17 \\
\hline $\begin{array}{l}\text { Calcium-channel } \\
\text { blocker }\end{array}$ & 1 cap., twice a day & $46.9 \%$ & $90.5 \%$ & 14 & 7.43 & 1.33 \\
\hline $\begin{array}{l}\text { Angiotensin-converting } \\
\text { enzyme inhibitor }\end{array}$ & 1 cap., $3 x /$ day & $48.3 \%$ & $92.4 \%$ & 21 & 10.86 & 1.60 \\
\hline
\end{tabular}

Abbreviations: cap.: capsule. \%: percentage.

Table 3. Pre- and post-test scores and significance of differences found.

\begin{tabular}{|c|c|c|c|}
\hline Tests & $\begin{array}{l}\text { Pre-test score (mean } \pm \text { standard } \\
\text { deviation [median]) }\end{array}$ & $\begin{array}{c}\text { Post-test score (mean } \pm \\
\text { standard deviation [median]) }\end{array}$ & $p^{*}$ \\
\hline \multicolumn{4}{|l|}{ Overall Group } \\
\hline Concordance (LatConIIB) & $38.67 \pm 3.69(40)$ & $40.14 \pm 5.65(42)$ & 0.086 \\
\hline \multicolumn{4}{|l|}{ Group of medical Students } \\
\hline Concordance (LatConlIB) & $38.79 \pm 3.51(40)$ & $40.86 \pm 5.71(42)$ & 0.069 \\
\hline \multicolumn{4}{|c|}{ Group of medical Interns and Residents } \\
\hline Adherence (BMQA) & $6.29 \pm 1.25(6)$ & $6.86 \pm 1.35(7)$ & 0.280 \\
\hline
\end{tabular}

Abbreviations: BMQ: Brief Medication Questionnaire ${ }^{17}$. LatConll: Leeds Attitude to Concordance II ${ }^{18}$.

*Wilcoxon Test.

In the pre-simulation concordance questionnaire, $60 \%$ of the participants agreed that it is not always necessary to consider the patients' point of view to adequately prescribe medications, while $96 \%$ strongly agreed that a good therapeutic decision is made when both doctor and patient agree on the treatment. to be used. The absolute concordance scores at both times of the study are shown and compared in Table 3. It was not possible to obtain significant data on the impacts of the simulation. 
Chart 1. Percentage of responses per item by question of concordance, before the simulation.

\section{It is not always necessary for physicians to consider the patients' priorities}

Patients must be able to take as much responsibility as they want for their own treatment

During the doctor-patient consultation, the patient's decision is the most important one

A good therapeutic decision is made when both doctor and patient agree on the treatment to be used

The consultation between doctor and patient should be seen as a negotiation between equals

The doctor is the expert and the patient's role is to do what the doctor says

Taking into account the patient's point of view is not always necessary to adequately prescribe medications

Doctors should encourage patients to express their concerns about taking medication

The doctor and the patient must find a compromise on what the problem is and agree together on what will be done

It is sometimes appropriate for the physician to make treatment decisions without the patient's manifestation

It is always important that the physicians listen to the patient's own understanding of their condition

Doctors should be more sensitive to how patients react to information given by doctors themselves

Doctors should make it clear when the benefits of a medication are uncertain

Physicians should give patients the opportunity to speak their minds about their diseases

During the consultation, both doctor and patient should express their views on possible treatments

Doctors should try to help patients make as informed a choice as possible about the benefits and risks of alternative...

Treatments are best used when they are what the patient wants and is able to achieve

Patient involvement in the prescription process always leads to better outcomes

Doctors and patients must agree on a treatment plan that considers both points of view

The prescription must consider the patient's expectations about the treatment

I disagree $\quad$ | agree $\quad$ | strongly agree

\section{DISCUSSION}

Therapeutic adherence results in a reduction in hospital readmissions and improves disease control ${ }^{19}$. Difficulties for good therapeutic adherence can vary with the prescribed regimen, the patient ${ }^{20}$ and the underlying disease. In Brazil, there are drugs available in the public care network only in specific dosages, rarely in combinations in a single pill or in easy dosages ${ }^{19,21}$. It is important to weigh the higher cost of more palatable dosages or even the use of certain medications known as "high-cost medications" against the potential and currently unmeasured savings of better adherence rates with better health outcomes ${ }^{13}$.

If the patient does not adhere, scientific advances in treatment are invalidated in practice. Although the physician's goal is to promote a good relationship between doctor and patient and, ultimately, to have their collaboration, physicians are imprecise in predicting the degree of adherence, which interferes with decisions and prevention ${ }^{22}$. Incidentally, even if they are inaccurate in measuring adherence, physicians are able to perceive satisfactory concordance and prompt an actual follow-up of the therapy, the more they discuss with the client ${ }^{22}$, a role that can be shared with the pharmacist ${ }^{3}$.

It is essential, then, to improve the professionals' skills, so they can build a favorable environment for the pharmacotherapy success. Although it is difficult to fully assess the nuances of socio-educational experiments, "role reversal" simulations, like the present study, seem to be the most capable of achieving this goal ${ }^{16}$. 
In numerical terms, considering that there are approximately 240 undergraduate students from the $5^{\text {th }}, 6^{\text {th }}$ and $7^{\text {th }}$ semesters at the institution, the group's participants represented approximately $8.75 \%$ of this population, despite the wide dissemination of the project. A relevant fact was the number of volunteers, 12 of 44 or $27 \%$, who were excluded due to drug use at the time of the study, since the population is young. The use of psychiatric medications is questioned, since the global mean prevalence of anxiety disorder among medical students is about one third ${ }^{23}$ and depression is also a cause of morbidity in the group.

As expected, the participants adhered less to largesize medications (metformin) and to more than one intake during the day (angiotensin-converting enzyme inhibitor and calcium channel blocker). However, the reported difficulty was not necessarily related to lower adherence, which may imply a projection of the difficulties that a patient would face. In the simulation carried out by Ulbrich et al., the best adherence results occurred with placebo using a dosage of once a day, independently from mealtimes, which was true only for the group of students, and not for the interns and residents.

A different percentage regarding the adherence to levothyroxine was observed among students (77.86\%) and interns and residents (42.86\%), which can be explained by the non-observation of fasting or because of the academic workload. In fact, there was a difference in absolute numbers regarding the percentage of adherence for all placebos between the two groups, consistently lower in the more advanced group, which may be a result of the demands of the professional routine, better able to simulate the patients' daily life routines, although this group expected a remarkably high adherence. The dissociation between prediction and the actual performance may be part of the origin of the physician's poor predictive capacity of the patient's adherence and concordance, as observed by Philips et al.

Most of the participants' responses to the concordance questionnaire were adequate, according to the data that has been discussed in this article about the physician's adequate attitude at the time of prescription, although they still show evidence of notions of benevolent authority, as shown by the high assent to the sentences "It is not always necessary for physicians to consider the patients' priorities" or "The physician is the expert and the patient's role is to do what the physician says." As shown in Table 3, there was an absolute difference in the agreement rates between the pre- and post-simulation moments, indicating a possible benefit of the experience, but without statistical significance.

Low adherence is usually not reported by the patient: the first step is to identify $\mathrm{it}^{24}$. The harm of the lack of practical discussions and simulations that promote empathy and alterity was found during the research, as shown by the small number of individuals interested in participating. In another study by Blackwell et al., the attitude of medical students on the subject was similar to that of patients with asymptomatic diseases, tending to under-medication and not being taught about the substantial significance of the placebo effect and lack of adherence in therapeutic outcomes ${ }^{25}$. Although this study does not show all of its results as being significant, it indicates the absence, applicability and effectiveness of simulations that challenge medical students and physicians to experience client limitations. The experiment sought to contribute to the realistic and empathetic perception of the volunteers, sensitize the student body and guide new curriculum guidelines.

The limitations of the present analysis were the small number of volunteers, the selection bias for attracting a specific student profile, the failure of part of the sample to complete the concordance tests, and the absence of a control group. The non-validation of the Portuguese concordance questionnaire, used here as a free translation, should motivate further studies. We emphasize the potential usefulness of utilizing the Leeds Attitude to Concordance II instrument, which is valid here because it constitutes a didactic tool.

\section{CONCLUSION}

Adherence to therapies is mediated by variables such as trust, communication and empathy, which, even though they cannot be effectively measured, are intrinsically related to the assessed subject. Efforts to promote the professionals' acknowledgment of beliefs, fears and challenges faced by patients should not be postponed in medical education.

The present study performed a simulation among medical students of polypharmacy patients, correlating theoretical knowledge with routine experience, in which the volunteers identified different adherence difficulties for each drug and had more difficulty in adhering than they expected. The combined impact on the perception of the therapeutic adherence complexity is essential for the professional to be encouraged to seek to acquire interpersonal communication skills and to act on behalf of the patient.

Additional studies with a larger sample that can challenge medical students to experience the daily therapeutic limitations of their patients are needed, confirming the hypothesis of the relevance of polypharmacy simulation as a positive influence on learning and as an important part of medical education curricula.

\section{AUTHORS' CONTRIBUTION}

Rafael D. Sarubbi and Antônio Brazil Viana Júnior contributed 
to the study concept and design, analysis and interpretation of data and writing of the manuscript. Yuri M. Bezerra and Isabelle de Sousa Pereira contributed to the analysis and interpretation of data and the writing of the manuscript. Ana Rosa P. Quidute contributed to the study concept and revision of the manuscript.

\section{CONFLICTS OF INTEREST}

The authors declare no conflicts of interest.

\section{SOURCES OF FUNDING}

The authors declare no sources of funding.

\section{REFERENCES}

1. Bireme, Opas. DeCS - Descritores em Ciências da Saúde [access in 16 sep 2020]. Available from: http://decs.bvs.br/.

2. Ulbrich T, Hamer D, Lehotsky K. Second-year pharmacy students' perceptions of adhering to a complex simulated medication regimen. Am J Pharm Educ. 2012;76(1):11. doi: 10.5688/ajpe76111.

3. Bubalo J, Clark RK Jr, Jiing SS, Johnson NB, Miller KA, Clemens-Shipman CJ, et al. Medication adherence: pharmacist perspective. J Am Pharm Assoc. 2010;50(3):394-406. doi: 10.1331/JAPhA.2010.08180.

4. Jannuzzi FF, Cintra FA, Rodrigues RCM, São-João TM, Gallani MCBJ. Medication adherence and quality of life among the elderly with diabetic retinopathy. Rev Lat Am Enfermagem. 2014;22(6):90210. doi: 10.1590/0104-1169.3477.2494.

5. de Albuquerque DC, de Souza Neto JD, Bacal F, Rohde LEP, BernardezPereira S, Berwanger O, et al. I Brazilian Registry of Heart Failure - Clinical Aspects, Care Quality and Hospitalization Outcomes. Arq Bras Cardiol. 2015;104(6):43342. doi: 10.5935/abc.20150031.

6. Chatkin JM, Blanco DC, Scaglia N, Wagner MB, Fritscher CC. Impact of a low-cost and simple intervention in enhancing treatment adherence in a Brazilian asthma sample. J Asthma. 2006;43(4):263-6. doi: 10.1080/02770900600620459.

7. Oliveira-Santos M, Verani JFS, Klumb EM, Albuquerque EMN. Evaluation of adherence to drug treatment in patients with systemiclupus erythematosus in Brazil. Lupus. 2011;20(3):320-9. doi: 10.1177/0961203310383736.

8. Oliveira MG, Amorim WW, de Jesus SR, Rodrigues VA, Passos LC. Factors associated with potentially inappropriate medication use by the elderly in the Brazilian primary care setting. Int J Clin Pharm. 2012;34(4):626-32. doi: 10.1007/s11096-012-9656-9.

9. Galvao TF, Silva MT, Gross R, Pereira MG. Medication use in adults living in Brasilia, Brazil: a cross-sectional, population-based study. Pharmacoepidemiol Drug Saf. 2014;23(5):507-14. doi: 10.1002/pds.3583.

10. Instituto Brasileiro de Geografia e Estatística. Projeções da população [access in 16 sep 2020]. Available from: https://www.ibge.gov.br/ estatisticas/sociais/populacao/9109-projecao-da-populacao.html.

11. Gellad WF, Grenard JL, Marcum ZA. A systematic review of barriers to medication adherence in the elderly: looking beyond cost and regimen complexity. Am J Geriatr Pharmacother. 2011;9(1):11-23. doi: 10.1016/j. amjopharm.2011.02.004.
12. Pêgo-Fernandes PM, Pestana JOM, Garcia VD. Transplants in Brazil: where are we? Clinics. 2019;74:e832. doi: 10.6061/clinics/2019/e832.

13. Hansen R, Seifeldin R, Noe L. Medication adherence in chronic disease issues in posttransplant immunosuppression. Transplant Proc. 2007;39(5):1287-300. doi: 10.1016/j.transproceed.2007.02.074.

14. Hughes CM. Medication non-adherence in the elderly. Drugs Aging 2004;21:793-811. doi: 10.2165/00002512-200421120-00004.

15. Perdue TO, Jackson JT, Herring C, Garren K, Yocum RA Jr, Swanson M, et al. Medication simulation affects health provider students' attitudes about adherence and concordance. Simul Healthc. 2017;12(5):308-13. doi: 10.1097/SIH.0000000000000244.

16. Bearman $M$, Palermo $C$, Allen LM, Williams B. Learning empathy through simulation: a systematic literature review. Simul Healthc. 2015;10(5):30819. doi: $10.1097 /$ SIH.0000000000000113.

17. Svarstad BL, Chewning BA, Sleath BL, Claesson C. The Brief Medication Questionnaire: a tool for screening patient adherence and barriers to adherence. Patient Educ Couns. 1999;37(2):113-24 [access in 10 oct 2020]. Available from: https://linkinghub.elsevier.com/retrieve/pii/ S0738399198001074.

18. Knapp P, Raynor DK, Thistlethwaite JE, Jones MB. A questionnaire to measure health practitioners' attitudes to partnership in medicine taking: LATCon II. Health Expect. 2009;12(2):175-86. doi: 10.1111/j.13697625.2009.00545.x.

19. Toh MR, Teo V, Kwan YH, Raaj S, Tan S-YD, Tan JZY. Association between number of doses per day, number of medications and patient's noncompliance, and frequency of readmissions in a multi-ethnic Asian population. Prev Med Rep. 2014;1:43-7. doi: 10.1016/j.pmedr.2014.10.001.

20. Patton DE, Hughes CM, Cadogan CA, Ryan CA. Theory-based interventions to improve medication adherence in older adults prescribed polypharmacy: a systematic review. Drugs Aging. 2017;34(2):97-113. doi: 10.1007/s40266-016-0426-6.

21. Yap AF, Thirumoorthy $T$, Kwan YH. Systematic review of the barriers affecting medication adherence in older adults. Geriatr Gerontol Int 2016;16(10):1093-101. doi: 10.1111/ggi.12616.

22. Phillips LA, Leventhal EA, Leventhal $H$. Factors associated with the accuracy of physicians' predictions of patient adherence. Patient Educ Couns. 2011;85(3):461-7. doi: 10.1016/j.pec.2011.03.012.

23. Quek TT-C, Tam WW-S, Tran BX, Zhang M, Zhang Z, Ho CS-H, et al. The global prevalence of anxiety among medical students: a meta-analysis. Int J Environ Res Public Health. 2019;16(15):2735-19. doi: 10.3390/ ijerph16152735.

24. Brown MT, Bussell J, Dutta S, Davis K, Strong S, Mathew S. Medication adherence: truth and consequences. Am J Med Sci. 2016;351(4):387-99. doi: 10.1016/j.amjms.2016.01.010.

25. Blackwell B, Griffin B, Magill M, Bencze R. Teaching medical students about treatment compliance. J Med Educ. 1978;53(8):672-5. doi: 10.1097/00001888-197808000-00008. 